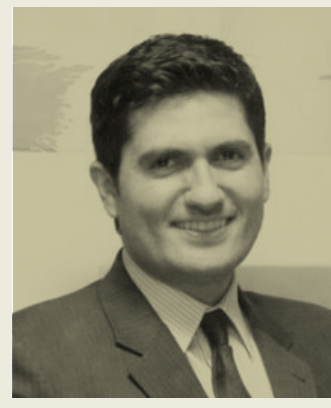

\title{
O MUNDO EM 2019
}

Nos últimos meses, o desgaste gerado pelo ciclo eleitoral canalizou a atenção de analistas e cidadãos para as idas e vindas da formação do governo de transição de Jair Bolsonaro. Pouco se falou de movimentos importantes na política internacional, como a manifestação dos coletes amarelos em Paris ou os desdobramentos das negociações do Brexit.

Além de buscarmos entender as dinâmicas internas que veremos a partir de 2019, também devemos pensar no mundo que o Brasil enfrentará, que não será fácil. Certas tendências que vieram se desenhando nos últimos anos tomam contornos mais complexos e impõem desafios ao país.

A primeira delas é a disputa - geopolítica e econômica - entre Estados Unidos e China. De um lado, a grande potência mundial, comandada por Donald Trump, vem redefinindo sua posição no mundo ao adotar medidas protecionistas, abandonar ou renegociar acordos e alianças multilaterais e aumentar o tom contra Rússia e China.

Já os chineses, sob a batuta de Xi Jinping, estruturaram a iniciativa econômica global mais ambiciosa desde o Plano Marshall, conhecida como Cinturão e Rota. Por trás dos investimentos trilionários em infraestrutura na Ásia e na África, há o desejo de firmar-se como alternativa a Washington.

A guerra comercial entre as duas maiores economias do mundo, deflagrada em 2018, é o principal indício dos perigos dessa nova ordem mundial. Ela já impôs impactos sobre grande parte dos países exportadores de grãos e minérios, além de produtos siderúrgicos - e pode continuar a afetar a dinâmica da economia global no próximo ano.

Em segundo lugar, há a onda de transformações políticas na Europa, em parte impulsionadas pelo ressurgimento do nacionalismo europeu, com contornos xenófobos e anti-integracionistas. Sintomas concretos disso são os impasses em torno do Brexit, o fortalecimento de lideranças populistas de direita na Itália, na Hungria e na Polônia, além da crise política na França, que expôs os limites de lideranças moderadas, como Emmanuel Macron.

A terceira tendência diz respeito à crise venezuelana. Relatos sobre a condição econômica e humanitária do país dão a medida da gravidade da situação de nosso vizinho, que vem trazendo impactos nas regiões fronteiriças de Colômbia e Brasil. O recente capítulo do envio de bombardeiros russos à Venezuela, supostamente para exercícios militares, pode trazer à América do Sul uma disputa geopolítica que não vemos, nesses cantos, desde o auge da Guerra Fria.

Temos, por fim, a crise global do multilateralismo. Estamos diante de um sistema de governança internacional que se tornou incapaz de endereçar as principais questões da humanidade. As prolongadas guerras da Síria e do Iêmen, as irrefreáveis mudanças climáticas e a aguda crise migratória global geraram respostas coletivas ainda insuficientes. A artilharia de lideranças como Trump e Bolsonaro contra a Organização das Nações Unidas (ONU) só agrava a disfuncionalidade desses mecanismos.

Diante das turbulências do mundo que nos aguarda em 2019, espera-se que o novo governo brasileiro crie condições para lidar com essas transformações. Mesmo que os desafios ao Brasil sejam grandes, eles não são insuperáveis. Para isso, serão necessários pragmatismo, senso de oportunidade e, sobretudo, prioridades. 